\title{
BenefitsofEconomic Liberalization in Growth and Development of Industry: With Reference to Butwal Industrial Area of Nepal
}

Bal Krishna Man Singh

PhD Scholar (MUR 1403003), Mewar University, Chittorgarh, Rajasthan, India and

Prof. Dr. BishwambherPyakuryal

Research Supervisor, Mewar University, Chittorgarh, Rajasthan, India

Email:bishwambher@gmail.com

Corresponding Author

Bal Krishna Man Singh

Email: bkmansingh94@gmail.com

Received: March 12, 2021; Revised \& Accepted: March 24, 2021; Published: June 30, 2021

(C) Copyright: Singh (2021).

\begin{abstract}
Economic liberalization policy is important to speed up the development activities. Nepal has been following the policy of economic liberalization since the mid-1980s which was accelerated with the start of 1990s. Nepal adopted economic liberalization to minimize public expenditure burden of loss-making public enterprises, mobilize private savings, investments, and FDI (Foreign Domestic Investment) as well as to meet Multilateral Donors conditions of economic reform. The study was conducted to identify the benefit of economic liberalization in industrial growth and development in Nepal. The study was conducted in the Butwal area of Province 5. It was a cross-section study based on the quantitative design. There was total 385 respondents selected from among the industrialists, traders, and bankers. The result shows that there were positive impactson the various economic indicators of industry like quantitative restrictions in trade had been removed, bilateral trade agreement facilitated free flow of goods and services, deregulated the monopoly of market, controlling in price structure, privatization of public services, flexibility in the exchange rate, elimination of import license and quotas, liberalization of foreign investments, High and sustained growth through market-based resource allocation, infusion of competition in the economy, reduction of state domination, and encouragement of private participation in economic activities were the added advantages of liberalization. There was significant difference in the response of industrialists, traders and bankers on benefit of economic liberalization in industrial growth and development in Nepalsuch as promotion of free trade, deregulation of the monopoly market, elimination of subsidies, price controls and other more benefits.
\end{abstract}

Keywords: Benefit, Economic liberalization, Growth and development, Industry, Nepal 


\section{INTRODUCTION}

Economic liberalization helps to bind the process that includes the government policies promoting free trade, deregulation, elimination of subsidies, price controls and privatization of public services (Thirlwall, 2000). Encouraged by the progress made by countries following liberal economic policy (East Asia), in the 1970s, developing countries have started giving preferences to economic liberalization to adjust the policies mostly for lending set by international financial institutions. Even though, there were contents and discontents about the economic liberalization, the momentum to the reform process further accelerated in ' $80 \mathrm{~s}$. As government had policies that were redirected to follow a noninterventionist approach to economic activity, depending on market forces for the distribution of resources. It was believed that market-based policy reforms would help to grow rate of poverty reduction. So, the government intervention in market is inefficient. Moreover, if interventionist does with good intentions, it doesn't have ability to manage the economy. Moving scarce resources into less productive economic activities helps to reduce the overall economic growth with greater consequences for poverty reduction. For rational, self-interested individuals maximize their economic benefits and overall economic welfare.

When economic growth rises, there will be the reduction of poverty. Distribution and social justice could benefit from the economic growth. Free market will help to bring about economic expansion through labor intensive export activities. This also creates employment to the people and thus, improves the well-being of the society (Dollar \& Kraay, 2002). The key features of liberalization included devaluation and introduction of flexibility in the exchange rate, elimination of import license and quotas, rationalization of the tariff structure, reduction in the average level of tariffs, implementation of full convertibility of the rupee in the current account, liberalization of foreign investments, privatization and institutional reform of stateowned enterprises, market-based pricing of agricultural inputs and outputs, and reduction of subsidies on credit and irrigation(Bhatta \& Sharma, 2006). Thus, liberalization is one of the important prerequisites to have development progress in the society. It helps to create conditions for a fluctuating market process development, in which it materializes itself. This type of liberalization impact on the national economy and has a very important character in connection with which it acts as an invisible productive force (Hill, 2010). Foreign Direct Investment (FDI) is the net inflows of the investment in a country, which is widely believed to have positive effects in the economy of a country. Any investment that flows from one country into another is known as foreign investment. As such, foreign investment is "encouraged since it complements and stimulates domestic investments in capital scarce economies of developing countries" (Cristina \& Levieuge, 2013).

Nepal has been following the policy of economic liberalization since the mid-1980s which was accelerated with the start of 1990s (Shrestha, 2017). Nepal adopted economic liberalization to minimize public expenditure burden of lost public enterprises, mobilize private savings, investments, and FDI (Foreign Domestic Investment) as well as to meet Multilateral 
Donors conditions of economic reform. Despite controversy on economic liberalization and privatization process, all sectors were liberalized for private and foreign investment through Industrial and Foreign Direct Investment (FDI) Policy of 1992 (HMG, 1993), except for a few national sensitive areas (Bista, 2017). With the economic liberalization process, Nepal has dismantled many restrictions and conditions imposed previously for the private sector to carry out various economic activities. The country opened the current account in 1993 and lowered import tariffs and introduced liberal industrial policy, foreign direct investment policy and trade policy. In addition, Nepal also liberalized the financial sector, resulting in the tremendous expansion of the financial sector. Nepal became the first Least Developed Countries (LDC) to become a member of World Trade Organization (WTO) in 2004. As a result of removal of administrative barriers, some economic sectors such as finance, communication, transport, health and education have expanded substantially. However, after a few years of expediting the economic liberalization process, political instability and armed internal conflict began in Nepal in 1996. After a decade, the armed conflict ended in 2006 with a comprehensive peace treaty with the rebel party. After the peace treaty, Nepal is in the process of state restructuring in a tardy pace, but the policy of economic liberalization has been kept unchanged even after the start of peace process (Shrestha P. K., 2017).

\section{National Policies related to Economic Liberalization}

The Eight five-year plan document of Nepal stipulated clearly the new liberal economy policy which aimed not only to promote private sector but also creating an environment to nongovernmental organization, cooperatives, local bodies and grass root organizations, to achieve the goals of economic development. The objective was to make macroeconomic stability, increase national production, creating employment, and development of backward areas and social justice in favor of the under privileged and economically marginalized people. The plan committed itself to dismantling the overbearing regulatory edifice of the past (Mahat, 2020). Similarly, Nepal Government has been promulgated the Privatization Act 2050 to carry out the privatization program effectively with the help of the legal framework needed for the program. The act has incorporated the provision of the organization set up, method of privatization, bid evaluation criteria, and method to make transactions transparent etc. (Manandhar \& Bajracharya, 2000). The government has envisaged a privatization program to build the competitive edge of the economy by bringing in private capital and management and by reducing the "crowding out" effects of public sector investment.

Interest rate deregulation started in November 1984 with partial freedom provided to the commercial banks to fix the interest rates from 1.0 percentage points to 1.5 percentage points above the minimum administered rates for different types of term deposits. In May 1986, this range was eliminated, allowing the banks to offer higher interest rates to any level above the fixed minimum level. In August 1989, the interest rate was completely deregulated. Since then, commercial banks and financial institutions are free to set both the deposits and loans rates. The objective of interest rate deregulation was to let the market decide the true cost of capital, keep 
real deposit rates positive, thereby, stimulating savings and creating a competitive environment in the financial system so as to benefit both the depositors and borrowers (Khatiwada, 1999; Shrestha M. B., 2005).The Nepal Rastra Bank Act 1955 was revised in 2001. This Act has made NRB an autonomous institution. As in other developing countries, the central bank of Nepal Nepal Rastra Bank previously had to work under government control. As a result, the bank could not implement monetary policies as well as financial sector policies independently. It is expected that the revised Act will serve the requirements of a modern central bank as part of the government's overall financial sector development and modernization program (Pyakuryal, 2002; Shrestha M. B., 2005).

The economic liberalization has brought changes with the reformation of other policies also like: a. the Administrative Reform Constitution, 1992 b. Public Expenditure Review Commission c. A rural development fund d. Forest management by Committee. e. Poverty Alleviation Fund. F. Youth Self Employment Scheme

\section{OBJECTIVE OF THE STUDY}

The main objective of this study is to identify the experiences and perception ofNepalese industrialists, traders and Bankerstowardsthe benefit of economic liberalization in industrial growth in Nepal.

\section{RESEARCH HYPOTHESIS}

There was no significant difference between the respondents regarding their response on benefit of economic liberalization in industrial growth in Nepal.

\section{MATERIALS \& METHODS}

The study was conducted in the Butwal area of Province 5 of Nepal because this area has been becoming the new industrial hub. The primary respondents of this study were industrialist, traders and bankers who are directly related with the activities and impact of economic liberalization. The study had selected 385 respondents by using the simple random sampling technique. The sample size was calculated by considering the $95 \%$ confidence interval, .05 margin of error, and .5 estimated prevalence. The structured survey questionnaire was used to collect the data. It was a cross-section study followed the descriptive as well as explanatory research design. It was fully based on quantitative design because statistical models were run to analyze the data. The study has described the response of respondents and also shown the relationship between the respondents in their response. The frequency table, mean, ANOVA and post Hoc Tests were used to analyze the data.

\section{RESULT \& DISCUSSION}

In this section, we examined the benefit by adopting economic liberalization in the country. Researcher had asked different questionnaire to examine the benefits adopting the economic liberalization. Table 1 shows the benefits by adopting economic liberalization in the country like promotion of free trade, deregulates the monopoly market, elimination of subsidies, 
price controls, promote fair and free price mechanism, liberalization of foreign investment, privatization and institutional reform of state-owned enterprises, high and sustained growth through market-based resource allocation, reduction of state domination, and encouragement of private participation in economic activities. It showed that most of the people has agreed with the statement.

Table 1: benefit by adopting economic liberalization in the country SD - Strongly Disagree, D - Disagree, N - Neutral, A - Agree, SA - Strongly Agree

\begin{tabular}{|c|c|c|c|c|c|c|}
\hline Statement & $\begin{array}{l}\text { SD } \\
(\%)\end{array}$ & $\begin{array}{l}\text { D } \\
(\%)\end{array}$ & $\begin{array}{l}\mathbf{N} \\
(\%)\end{array}$ & $\begin{array}{l}\text { A } \\
(\%)\end{array}$ & $\begin{array}{l}\text { SA } \\
(\%)\end{array}$ & Mean \\
\hline Economic liberalization Promotes free trade & 2.6 & 7.3 & 13.8 & 53.2 & 23.1 & 3.8701 \\
\hline Economic liberalization Deregulates the monopoly market & 3.4 & 10.1 & 22.3 & 42.6 & 21.6 & 3.6883 \\
\hline Elimination of subsidies & 11.2 & 28.1 & 18.2 & 30.4 & 12.2 & 3.0442 \\
\hline Price controls & 3.6 & 17.7 & 22.3 & 38.7 & 17.7 & 3.4909 \\
\hline Rationing systems, & 3.1 & 20.0 & 29.4 & 34.3 & 13.2 & 3.3455 \\
\hline Downsizing or privatization of public services & 2.1 & 15.3 & 23.9 & 38.2 & 20.5 & 3.5974 \\
\hline Fair and free price mechanism and competition & .8 & 10.1 & 19.5 & 42.9 & 26.8 & 3.8468 \\
\hline Devaluation and introduction of flexibility in the exchange rate, & 2.9 & 10.4 & 35.3 & 43.4 & 8.1 & 3.4338 \\
\hline Elimination of import license and quotas, & 3.9 & 14.3 & 29.6 & 41.8 & 10.4 & 3.4052 \\
\hline Rationalization of the tariff structure, & 5.2 & 22.1 & 27.3 & 36.6 & 8.8 & 3.2182 \\
\hline Reduction in the average level of tariffs, & 7.5 & 24.4 & 26.8 & 34.0 & 7.3 & 3.0909 \\
\hline $\begin{array}{l}\text { Implementation of full convertibility of the rupee in the current } \\
\text { account, }\end{array}$ & 4.9 & 16.6 & 35.8 & 36.9 & 5.7 & 3.2182 \\
\hline Liberalization of foreign investments, & 9.6 & 13.5 & 25.2 & 39.7 & 11.9 & 3.3091 \\
\hline Privatization and institutional reform of state-owned enterprises, & 4.2 & 12.7 & 31.9 & 37.9 & 13.2 & 3.4338 \\
\hline Market-based pricing of agricultural inputs and outputs, & 4.4 & 9.4 & 30.4 & 43.1 & 12.7 & 3.5039 \\
\hline Reduction of subsidies on credit and irrigation & 4.2 & 15.3 & 24.2 & 44.2 & 12.2 & 3.4494 \\
\hline $\begin{array}{l}\text { High and sustained growth through market-based resource } \\
\text { allocation, }\end{array}$ & 1.0 & 11.7 & 28.6 & 43.4 & 15.3 & 3.6026 \\
\hline Infusion of competition in the economy, & 1.8 & 4.7 & 20.8 & 47.0 & 25.7 & 3.9013 \\
\hline Reduction of state domination & 3.4 & 18.2 & 16.6 & 39.7 & 22.1 & 3.5896 \\
\hline Encouragement of private participation in economic activities & 1.8 & 5.2 & 19.2 & 49.6 & 24.2 & 3.8909 \\
\hline
\end{tabular}

Source: Field Survey, 2020

It can be interpreted that most of the people agreed with the given statement. Most of the people agreed $(49.6 \%)$ with the statement that encouragement of private participation in economic activities helps to benefit by adopting economic liberalization in the country with mean of 3.8909, while least of the people strongly disagreed with the statement $(1.8 \%)$. Similarly, mean was most for the infusion of competition in the economy (3.9013) and least for the elimination of subsidies (3.0442). Moreover, maximum percentage of respondents agreed $(53.2 \%)$ that economic liberalization promotes free trade while least of the people strongly disagreed $(2.6 \%)$ with the statement. In addition, about $23.1 \%$ of the people strongly agreed with the statement. They believed that this would benefit by adopting economic liberalization in the 
country. In addition, most of the people (42.6\%) believed that economic liberalization deregulates the monopoly market while least of the people (3.4\%) strongly disagreed with the statement. Mean of the statement was 3.6883. About $22.3 \%$ of the people were neutral with the statement.

Similarly, maximum percentage of the people (30.4\%) agreed with elimination of subsidies was benefited by adopting economic linearization in the country with the mean value of 3.0442, while least percentage of people strongly disagreed (11.2\%) with the statement. Apart from this, $28.1 \%$ of the people disagreed with the given statement while $18.2 \%$ were neutral and $12.2 \%$ of the people strongly agreed with the statement. Moreover, price controls are also benefited by adopting economic liberalization in the country with mean 3.4909. It was seen that most of the people agreed (38.7\%) with the statement. About $22.3 \%$ of the respondents were neutral while $17.7 \%$ of the people disagreed with the statement. At least $3.6 \%$ of the people strongly disagree with the statement.

In overall, majority of the respondents of this studyagreed with the rationing system, downsizing or privatization of public services, fair and free price mechanism and competition, devaluation and introduction of flexibility in the exchange rate, elimination of import license and quotas, rationalization of the tariff structure, reduction in the average level of tariffs, implementation of full convertibility of the rupee in the current account, and liberalization of foreign investments were benefited by the economic liberalization in the country. Similarly, it was followed by privatization and institutional reform of state-owned enterprises, market-based pricing of agricultural inputs and outputs, reduction of subsidies on credit and irrigation, high and sustained growth through market-based resource allocation, infusion of competition in the economy, and reduction of state domination.

\section{Mean differences between Industrialist, Traders and Bankers}

Banker is an individual who works as part of a financial organization and related to gain of capital for the institution or government. They have good knowledge and have abilities along with verbal and written communication that are required for the work. Banker helps in economizing the use of money, and diminishes the cost and effort of exchange (Monvoisin \& Sandrine, 2012). Similarly, trader engages in buying and selling of assets from or within the market. Trader can hold the assets for shorter period unlike investors. They are also engaged in international trade. International trade means the exchange of capital, goods, and services across international borders or territories. As countries needs goods and services to fulfill the requirement of people, trader help to fulfill such demands. Due to limited resources in certain countries, other countries or place fulfill the requirements of people (Grozdanovska, Jankulovski, \& Bojkovska, 2017). Industry is a group of companies that are related based on their business. There are different categories of industrial classification. Growth of industry has played crucial role in development of country in terms of economy. Early industrialization occurred in Europe and North America during $18^{\text {th }}$ and $19^{\text {th }}$ centuries and it was expanded on other parts of the world. With different level of success, numerous strategies for industrialization have been 
implemented (Investopedia, 2021). In Nepal, growth of industry is not significant but it has helped in economy of country. It has also provided employment to the people.

It was very important to know the mean difference between industrialist, traders and bankers in relation to their experience on benefit of economic liberalization in economic development of Nepal through the effective implementation in industrial sectors. Table 2 shows the mean difference between them. It shows that maximum mean was obtained for banker (77.2813) followed by industrialist (69.9609) and trader (68.8667).

Table 2: Mean differences between Industrialist, Traders and Bankers

\begin{tabular}{|c|c|c|c|c|c|c|c|c|}
\hline \multicolumn{9}{|l|}{ Descriptives } \\
\hline III & \multirow[t]{3}{*}{$\mathrm{N}$} & \multirow[t]{3}{*}{ Mean } & \multirow[t]{3}{*}{ Std. Deviation } & \multirow[t]{3}{*}{ Std. Error } & \multirow{2}{*}{\multicolumn{2}{|c|}{$\begin{array}{l}95 \% \text { Confidence Interval for } \\
\text { Mean }\end{array}$}} & \multirow[t]{3}{*}{ Minimum } & \multirow[t]{3}{*}{ Maximum } \\
\hline & & & & & & & & \\
\hline & & & & & Lower Bound & Upper Bound & & \\
\hline Industrialist & 128 & 69.9609 & 8.72629 & .77130 & 68.4347 & 71.4872 & 49.00 & 92.00 \\
\hline Trader & 225 & 68.8667 & 8.37087 & .55806 & 67.7670 & 69.9664 & 43.00 & 91.00 \\
\hline Banker & 32 & 77.2813 & 6.21774 & 1.09915 & 75.0395 & 79.5230 & 66.00 & 92.00 \\
\hline Total & 385 & 69.9299 & 8.62245 & .43944 & 69.0659 & 70.7939 & 43.00 & 92.00 \\
\hline
\end{tabular}

Source: Field Survey, 2020

It can be interpreted that out of 385 total respondents, 128 were industrialist, 225 were trader and 32 were banker. The total mean was 69.9299 with standard deviation of 8.6225 and standard error of 0.43944 . The minimum and maximum value was found to be 43.000 and 92.000 respectively.

Specifically, there were 128 industrialists with mean of 69.9609 and standard deviation of 8.7263. Upper and lower bound confidence interval was 71.4872 and 68.4347 respectively. Similarly, 225 respondents were traders with mean of 68.8667 and standard deviation of 8.3709. Minimum and maximum value was 43.0000 and 91.0000. Moreover, there were 32 bankers to respond the benefit. The mean difference between the bankers was 77.2813 with standard deviation of 6.2177. Lower and upper bound confidence interval (95\%) for mean was 75.0395 and 79.5230 respectively.

In general, comparatively, Bankers were found more positive towards the benefit of economic liberalization in economic development of Nepal. Experience of industrialists and traders were almost similar.

\section{ANOVA of Benefit of economic liberalization}

ANOVA means analysis of variance. It was developed by Ronald Fisher in 1918. It is more extension of the $t$ and $z$ test. T-test is not applied when there are more than two groups. So, this is limited by ANOVA. It helps to do analysis of variance between and within the groups whenever the groups are more than two. ANOVA helps to test several null hypotheses at the same time. Use of ANOVA depends more on research design (Statistics Solutions, 2013). ANOVA test is used to find whether the results of survey are significant or not. In other words, it 
is used to know the influence of independent variables on the dependent variables in a regression study. It is analyzing factors that affect a given data set. It compares more than two groups at the same time to know the relationship between them (Kenton, Analysis of Variance (ANOVA), 2021).

Researcher prefer ANOVA test in many ways than others. Researcher uses ANOVA in three ways as one-way ANOVA, two-way ANOVA, and N-way multivariate ANOVA. One-way ANOVA is used to compare more than two groups based on one independent variable. Similarly, two-way ANOVA is used to compare the groups based on two factors. It is used to see the effect of one of the factors after controlling for other, or it is also used to know the interaction between the two factors (Cortina \& Nouri, 2000).Regression is used in different statistics such as finance, investing and others to determine the strength and character of the relationship between one dependent variable and a series of other independent variables. It helps to explain how the data series are generated. While sum of squares is a technique to determine the dispersion of data points. It helps to find the function that best fits from data (Kenton, 2020). In this relation, the study had also run the ANOVA.

The study tried to know the benefit of economic liberalization through ANOVA. Table 3 shows the ANOVA of benefit of economic liberalization. It showed that sum of squares was 28549.2730.

Table 3: ANOVA of Benefit of economic liberalization

ANOVA

\begin{tabular}{llllll} 
& Sum of Squares & Df & Mean Square & F & Sig. \\
\hline Between Groups & 1983.833 & 2 & 991.917 & 14.263 & .000 \\
Within Groups & 26565.273 & 382 & 69.543 & & \\
Total & 28549.106 & 384 & & & \\
\hline
\end{tabular}

Source: Field Survey, 2020

It can be interpreted from ANOVA test that sum of squares between the groups was 1983.833 while within the groups was 28549.106 . It also shows that the p-value was 0.000 which is less than 0.05 significant levels, so it indicates that there was significant difference between and within the groups of respondents in their response on benefit of economic liberalization. The statistical result of ANOVA rejected the hypothesis of this study.

\section{Post Hoc Tests of Benefit of economic liberalization}

Post Hoc test is used to test for multiple pairwise comparisons. Two approaches can be used to test the difference among the means in one-way analysis of variance (ANOVA) design or for means involved in the main effects in a factorial design. The use of a priori planned comparisons appropriate for testing specific hypothesis that were formulated prior to data collection and analysis. Thus, post hoc tests are an integral part of ANOVA. Post hoc tests are used to test differences between multiple groups of means while controlling the experiment-wise 
error rate (Holm \& Christman, 1985). Post hoc in Latin means after this and are used to see specific differences between three or more than three groups of mean when ANOVA f-test is significant. But at a time, it tests pair of groups. F-test doesn't give exact differences between which groups. Thus, post hoc test helps researcher to locate those specific differences and are calculated whether f-test is significant or not. If $\mathrm{f}$-test is non-significant then there is no need for the researcher to know for any specific differences (Allen, 2017).

Researcher had analyzed the data to identify the differences between the respondents in their response on benefit of economic liberalization through the analysis of Post Hoc Tests. Three types of respondents were taken in this survey and asked the questions related to benefit of economic liberalization in economic growth. Table 4 shows that the results of Post Hoc Tests.

Table 4: Post Hoc Tests of Benefit of economic liberalization

\begin{tabular}{|c|c|c|c|c|c|c|}
\hline \multicolumn{7}{|c|}{$\begin{array}{l}\text { Multiple Comparisons } \\
\text { Dependent Variable: Benefit } \\
\text { LSD }\end{array}$} \\
\hline \multirow[t]{2}{*}{ (I) Types of respondents } & \multirow[t]{2}{*}{ (J) Types of respondents } & \multirow{2}{*}{$\begin{array}{l}\text { Mean } \\
\text { Difference (I-J) }\end{array}$} & \multirow[t]{2}{*}{ Std. Error } & \multirow[t]{2}{*}{ Sig. } & \multicolumn{2}{|c|}{ 95\% Confidence Interval } \\
\hline & & & & & Lower Bound & Upper Bound \\
\hline \multirow{2}{*}{ Industrialist } & Trader & 1.09427 & .92324 & .237 & -.7210 & 2.9095 \\
\hline & Banker & $-7.32031^{*}$ & 1.64818 & .000 & -10.5610 & -4.0797 \\
\hline \multirow{2}{*}{ Trader } & Industrialist & -1.09427 & .92324 & .237 & -2.9095 & .7210 \\
\hline & Banker & $-8.41458^{*}$ & 1.57553 & .000 & -11.5124 & -5.3168 \\
\hline \multirow{2}{*}{ Banker } & Industrialist & $7.32031^{*}$ & 1.64818 & .000 & 4.0797 & 10.5610 \\
\hline & Trader & $8.41458^{*}$ & 1.57553 & .000 & 5.3168 & 11.5124 \\
\hline
\end{tabular}

*. The mean difference is significant at the 0.05 level.

Source: Field Survey, 2020

We can interpret that there was no significant difference between trader and industrialist. The obtained $p$-value was 0.237 which was greater than 0.05 . The mean difference between industrialist and trader was 1.0943 with standard error of 0.9234 . However, there was significant difference between industrialist and banker. The p-value between them is 0.000 . Mean difference between them is -0.7320 with standard error of 1.6482 . Similarly, there was significant difference between trader and banker as the p-value (0.000) is less than standard p-value of 0.05. Mean difference between them is 8.4146 with standard deviation of 1.5755 .

Finally, the results showed that there was difference in the response of industrialist and banker, and trader and banker, whereas there was similarity in the response of trader and industrialist.

\section{SUMMARY AND CONCLUSIONS}

Liberalization is also linked to Neoliberalism, which advocates privatization, deregulation, free trade, financial sector reform etc. Three countries Brazil, India and China are an example of success achieving fastest growth.Neoclassical theory was popular towards the end of 1970s during Margaret Thatcher in UK and Ronald Reagan in the USA. In 1980 the World Bank also shifted from Basic Needs Approach to Neo-classical Approach with trade 
liberalization, deregulation, privatization (economist John Williamson coined the word 'Washington Consensus' in 1989), and Structural Adjustment Programs (SAP) was advocated by the World Bank and IMF. The frequency of global financial crisis has now necessitated to reorient liberalization and globalization. The 'Washington Consensus' has therefore become out of the tune and hence obsolete.

The surveyed literature shows, liberalization and globalization are closely linked. The term globalization is however, recent. Academic literature categorizes globalization into three major areas: economic globalization, cultural globalization, and political globalization. In 2000, the International Monetary Fund (IMF) identified four basic aspects of globalization:trade and transactions; capital and investment movements; migration and movement of people; and dissemination of knowledge. The world is now taking advantage of economic liberalization through globalization.

From the analysis and observation of above findings, it can be concluded that economic liberalization has promoted the free trade, deregulated the monopoly of market, controlling in price structure, privatization of public services, flexibility in the exchange rate, elimination of import license and quotas, Liberalization of foreign investments, High and sustained growth through market-based resource allocation, Infusion of competition in the economy, Reduction of state domination, and Encouragement of private participation in economic activities. There was significant difference in the response of industrialists, traders and bankers on benefit of economic liberalization in industrial growth and development in Nepal. In general, comparatively, Bankers were found more positive towards the benefit of economic liberalization in economic development of Nepal. Experience of industrialists and traders were almost similar. Considering the importance of economic liberalization, future research can study on the impact of economic liberalization in economic development of Nepal.

\section{ACKNOWLEDGEMENT}

I would like to thanks all those respondents who were actively participated in the study to provide the data, and I also like to thanks all the enumerators for their support in data collection. I am thankful to all official and non-official friends and relatives to support me in this research work.

\section{Conflict of Interest}

Researcher here declared that there is no any conflict of interest.

\section{References}

Allen, M. (2017). The sage encyclopedia of communication research methods. Thousand Oaks, CA: SAGE Publications. 
Bhatta, S. R., \& Sharma, P. (2006). Trade Liberalization and Poverty: Case of Nepal . Trade Insight .

Bista, R. B. (2017, March ). ECONOMIC LIBERALIZATION IN NEPAL: DETERMINANTS, STRUCTURE, AND TRENDS OF FDI. The WINNERS, 18 (1), 33-41. doi:DOI: 10.21512/tw.v18i1.4051

Buchanan, J. M., \& Faith, R. L. (1980). SUBJECTIVE ELEMENTS IN RAWLSIAN CONTRACTUAL AGREEMENT ON DISTRIBUTIONAL RULES. Economic Impurity, 23-38.

Cortina, J. M., \& Nouri, H. (2000). Effect size for ANOVA designs. Thousand Oaks, CA: Sage.

Cristina, J. U., \& Levieuge, G. (2013). Growth effect of FDI in developing Economies: The role of institutional quality (No. 2251). Orleans Economics Laboratory, University of Orleans.

Dollar, D., \& Kraay, A. (2002). Growth is Good for the Poor. Journal of Economic Growth, 195-225.

Grozdanovska, V., Jankulovski, N., \& Bojkovska, K. (2017). International Business and Trade. International Journal of Sciences: Basic and Applied Research (IJSBAR), 105-114.

Hill, R. V. (2010). Liberalization and Producer Price Risk: Examining Subjective Expectations in the Ugandan Coffee Market. . Journal of African Economics, 433-458.

Holm, K., \& Christman, N. J. (1985). Post hoc tests following analysis of variance. . Research in Nursing \& Health, 207-210.

Investopedia. (2021, 3 7). Industrialization. Retrieved from Investopedia:

https://www.investopedia.com/terms/i/industrialization.asp

Kenton, W. (2020, 06 27). Sum of Squares. Retrieved from Investopedia: https://www.investopedia.com/terms/s/sum-of-squares.asp

Kenton, W. (2021, 02 21). Analysis of Variance (ANOVA). Retrieved from Investopedia: https:/www.investopedia.com/terms/a/anova.asp

Khatiwada, Y. R. (1999). Khatiwada, Yuba Raj (1999). "An Overview of Financial Liberalization and Agenda for Further Reforms", Do We Need Economic Reforms Phase II, . Kathmandu: Institute for Integrated Development Studies.

Mahat, R. S. (2020). Trials, Tremors and Hope, The Political Economy of Contemporary Nepal. 
Manandhar, D., \& Bajracharya, D. P. (2000). Privatization in Nepal. In D. Manandhar, \& D. P. Bajracharya, Privatization in South Asia . New Delhi: SAAT:ILO.

Monvoisin, V., \& Sandrine, A. (2012). The Banker, his Economic and Societal Function: History of a Fundamental and Infamous Activity. In Business Ethics: a critical approach (pp. 118-133). Routledge.

Pyakuryal, B. (2002). Financial Sector Reform in Nepal: Needs and Challenges. Pokhara, Nepal.: SEACEN Workshop on Macroeconomic Management.

Shrestha, M. B. (2005). Financial Liberalisation in Nepal. New South Wales, Australia: University of Wollongong.

Shrestha, P. K. (2017). Economic Liberalization in Nepal: Evaluating the Changes in Economic Structure, Employment and Productivity. Journal of Development Innovations, 1(1), 6083.

Shrestha, P. K. (2017, Feb. 28). Economic Liberalization in Nepal: Evaluating the Changes in Economic Structure, Employment and Productivity. Journal of Development Innovations, 1(1), 60 - 83. Retrieved Jun 1, 2021, from www.karmaquest.org/journal

Statistics Solutions. (2013). ANOVA (Analysis of Variance). Statistics Solutions, 1-10.

Thirlwall, A. P. (2000). Trade, Trade Liberalisation and Economic Growth: Theory and Evidence. AFRICAN DEVELOPMENT BANK, 1-29. 